\title{
Water Extractable Organic Carbon and Nitrogen and Their Natural Stable Isotopes from Long-Term Experiment in A Japanese Rice Paddy
}

\author{
Toan Nguyen-Sy ${ }^{1}$, Weiguo Cheng ${ }^{1,2}$, Julien Guigue ${ }^{2,5}$, Samuel Munyaka Kimani ${ }^{2}$, Wisnu Aji \\ $\mathrm{Wibowo}^{2}$, Keitaro Tawaraya ${ }^{2}$, Toru Watanabe ${ }^{2}, \mathrm{Ji} \mathrm{Wu}^{3}$ and Xingkai $\mathrm{Xu}^{4}$ \\ ${ }^{1}$ The United Graduate School of Agricultural Sciences, Iwate University, Morioka 020-8550, Japan \\ ${ }^{2}$ Faculty of Agriculture, Yamagata University, 1-23 Wakaba-machi, Tsuruoka, Yamagata 997-8555, Japan \\ ${ }^{3}$ Soil and Fertilizer Research Institute, Anhui Academy of Agricultural Sciences, Hefei, Anhui 230031, \\ China \\ ${ }^{4}$ State Key Laboratory of Atmospheric Boundary Layer Physics and Atmospheric Chemistry, Institute of \\ Atmospheric Physics, Chinese Academy of Sciences, Beijing 100029, China \\ ${ }^{5}$ Present address, Institute for Agro-Environmental Sciences, NARO, 3-1-3, Kannondai, Tsukuba, Ibaraki \\ 305-8604, Japan
}

\begin{abstract}
Hot water- and water-extracted organic matter was extracted from soil samples collected after a 31-year long-term experiment which is carrying out in Yamagata, northeastern Japan for single rice cultivation. The ratio of soil to extracted water was 2:3, lower than normal $(1: 5 \sim 1: 10)$ for $\delta^{13} \mathrm{C}$ and $\delta^{15} \mathrm{~N}$ measurements. The amounts of hot waterextracted organic carbon and nitrogen (HWEOC and HWEN) at $80^{\circ} \mathrm{C}$ and 16 hours, water-extracted organic carbon and nitrogen (WEOC and WEN) at room temperature, and their $\delta^{13} \mathrm{C}$ and $\delta^{15} \mathrm{~N}$ were measured from the five fertilizer treatment plots as [1) PK, 2) NPK, 3) NPK $+6 \mathrm{Mg} \mathrm{ha}^{-1}$ rice straw (RS), 4) NPK $+10 \mathrm{Mg} \mathrm{ha}^{-1}$ rice straw compost (CM1), and 5) NPK $+30 \mathrm{Mg} \mathrm{ha}^{-1}$ rice straw compost (CM3)], for surface (0-15 cm) and subsurface (15$25 \mathrm{~cm}$ ) layers. HWEOC and WEOC accounted for an average of about 1.51 and $0.66 \%$ of SOC, while HWEN and WEN accounted for an average of about 1.09 and $0.40 \%$ of soil TN, respectively. About $90 \%$ of the extracted N was organic form among all treatments. The $\delta^{13} \mathrm{C}$ values of $\mathrm{HWEOC}$ and WEOC ranged from -28.2 to $-26.5 \%$ and from -28.3 to $-27.0 \%$, similar to the original rice straw and rice straw compost, and lower than the value of original soil at $-22.5 \%$. The $\delta^{15} \mathrm{~N}$ values of HWEN, WEN and bulk soil ranged from 0.8 to $3.8 \%$, from 1.0 to $4.0 \%$, and from 0.8 to $2.8 \%$, respectively. It was clear that $\delta^{15} \mathrm{~N}$ decreased in RS but increased in CM3 treatments. Our results indicated that the amounts of hot water- and water-extracted organic matter were affected by long-term application of inorganic fertilizers and organic matters remarkably. However, the $\delta^{13} \mathrm{C}$ values of HWEOC and WEOC were not different among 5 treatments, but $\delta^{15} \mathrm{~N}$ values of HWEN and WEN were clearly affected by RS and CM3 applications.
\end{abstract}

Keywords: $\delta^{13} \mathrm{C}, \delta^{15} \mathrm{~N}$, hot water-extracted matter, long-term experiment, rice paddy

Faculty of Agriculture, Yamagata University, 1-23 Wakabamachi, Tsuruoka, Yamagata 997-8555, Japan.

\section{INTRODUCTION}

Long-term experiments (LTE) started more than one hundred years ago, with the first LTE initiated in 1843 at Rothamsted Experimental Station in England. Although the initial purpose of these LTEs was to understand the change in agrosystems productivity, it broadened over time to assess other impacts such as ecosystem perturbations, global environmental changes on agrosystems sustainability (Rasmussen et al., 1998; Körschens, 2006).

Correspondence Author: Weiguo Cheng, E-mail:
cheng@tds1.tr.yamagata-u.ac.jp

Observations from LTEs can provide an understanding of the characteristics and functional changes occurring in soils across time, to help in predicting soil productivity and soil-environment interactions (Richter et al., 2007; Hopkins et al., 2009). Compared to the early LTEs carried out in Europe and USA for uplands which were started before the 1900s (Körschens, 2006), the oldest LTE for lowlands rice (Oryza sativa L.) was started in 1926 in Anjo, Aichi Prefecture (Kanamori, 2000). Most of the LTEs on rice paddies have been 
conducted in Asian countries (Kanamori, 2000; Azuma et al., 2015; Cheng et al., 2016).

Carbon (C) and nitrogen (N) are two of the most important elements which determine soil sustainability and environmental impacts. Studying the $\mathrm{C}$ and $\mathrm{N}$ cycles in LTEs soils is crucial to understand the changes in soil quality, and effects on global warming as greenhouse gases are exchanged between the atmosphere and plant-soil ecosystems. The dynamics of soil organic $\mathrm{C}$ (SOC) and total $\mathrm{N}$ (TN) in submerged rice paddies is different from that of aerobic upland soils for wheat, maize and others, because submerged rice paddies are maintained at lower redox potentials during long periods. Natural stable isotopes of $\mathrm{C}$ and $\mathrm{N}\left(\delta^{13} \mathrm{C}\right.$ and $\delta^{15} \mathrm{~N}$ ) are widely used to study the dynamic of soil organic matter (SOM). The changes in $\delta^{13} \mathrm{C}$ and $\delta^{15} \mathrm{~N}$ in soils are based on the $\mathrm{C}$ and $\mathrm{N}$ sources and their discriminations during the cycling processes (Yoneyama et al., 2001; Cheng et al., 2005; Cheng et al., 2010; Werth and Kuzyakov, 2010; Nakajima et al., 2016; Choi et al., 2017). Among the different fractions of SOM, water-extracted organic matter (WEOM) represents a small fraction, involved in many soil processes (Chantigny, 2003; Guigue et al., 2014). WEOM has been widely used to extract in both moist soil and dry soil, since both water extracts of moist and air-dried soils are simple to obtain and can provide a labile organic matter. However, extracts from moist soil contain very little SOM derived from microbial cells compared to those of dry soil (van Ginkel et al., 1994). WEOM which obtain at room temperature can extract a substantial amount of SOM, but to maximize the amount of microbial material in a water extract of dry soils, hot water-extracted organic matter (HWEOM) which obtain at elevated temperature had been recommended (Sparling et al., 1998). Hot water-extracted organic C
(HWEOC) from air-dried soils has been used as an indicator of upland soil $\mathrm{N}$ availability, with an extraction temperature of $80^{\circ} \mathrm{C}$ and duration of 16 hours (Ghani et al., 2003; Curtin et al., 2006). The HWEOC of air-dried paddy soils showed high positive correlation to the available $\mathrm{N}$, which measured by anaerobic incubation method at $30^{\circ} \mathrm{C}$ for four weeks (Azuma et al., 2015). Although many LTEs researches on $C$ and $\mathrm{N}$ dynamics focused on WEOC and waterextracted $\mathrm{N}$ (WEN), there is no report on the combination of soil WEOC and WEN with their natural stable isotopes, $\delta{ }^{13} \mathrm{C}$ and $\delta{ }^{15} \mathrm{~N}$.

The objectives of this study were to determine the changes in the amounts of WEOC and WEN, HWEOC and HWEN, and of their C and $\mathrm{N}$ stable isotopes signatures, after long-term (31 years) application of two types of organic matter (i.e. rice straw and rice straw compost) combined with NPK fertilizers in a single rice paddy for a cold temperate region in Japan.

\section{MATERIALS AND METHODS}

\section{Site location and treatments}

The long-term experimental field is located at the Yamagata Integrated Agricultural Research Center, Yamagata, Japan $\left(38^{\circ} 15^{\prime} \mathrm{N}\right.$, $\left.140^{\circ} 15^{\prime} \mathrm{E}\right)$, a typical humid temperate climate zone. The mean annual temperature was $11.7^{\circ} \mathrm{C}$ and mean annual precipitation was $1163 \mathrm{~mm}$ over a period of 30 years (1981-2010), according to data recorded at Yamagata Meteorological Station. The long-term experiment was started in May 1982 with the first rice growing season. The soil is classified as Inceptisol by US Soil Taxonomy (Cheng et al., 2007). The initial soil had a $\mathrm{pH}\left(\mathrm{H}_{2} \mathrm{O}\right)$ of 5.56 , SOC of $8.9 \mathrm{~g} \mathrm{~kg}^{-1}$, and TN of $1.1 \mathrm{~g} \mathrm{~kg}^{-1}$ at the depth of $0-12 \mathrm{~cm}$. More information about this LTE can be found in Yamagata Agricultural Research Station (1983). 
Soil samples were collected from five plots of $100 \mathrm{~m}^{2}$ under different fertilizations: (1) PK, (2) NPK, (3) NPK + rice straw (RS), (4) NPK + rice straw compost (CM1), and (5) NPK + overdosed rice straw compost (CM3). Three fertilizers ammonium sulfate, monocalcium phosphate and potassium chloride applied annually corresponded to the rate $80 \mathrm{~kg} \mathrm{~N}: 68$ $\mathrm{kg} \mathrm{P}_{2} \mathrm{O}_{5}: 83 \mathrm{~kg} \mathrm{~K}_{2} \mathrm{O} \mathrm{ha}^{-1}$ (Table 1). Rice straw

Table 1. Details of the amounts of inorganic fertilizer and organic matter applied in the 5 treatment plot for each year, and the SOC and TN at surface $(0-15 \mathrm{~cm})$ and subsurface $(15-25 \mathrm{~cm})$ layers, respecitvely, after 31 years long-term treatments.

\begin{tabular}{|c|c|c|c|c|c|c|c|c|c|}
\hline \multirow[b]{2}{*}{ Treatment } & \multicolumn{3}{|c|}{$\begin{array}{l}\text { Inorganic fertilizer } \\
\qquad\left(\mathrm{kg} \mathrm{ha}^{-1}\right)\end{array}$} & \multicolumn{2}{|c|}{$\begin{array}{l}\text { Organic matter } \dagger \\
\qquad\left(\mathrm{Mg} \mathrm{ha}^{-1}\right)\end{array}$} & \multicolumn{2}{|c|}{$\begin{array}{l}\text { SOC contents* } \\
\qquad\left(\mathrm{g} \mathrm{kg}^{-1}\right)\end{array}$} & \multicolumn{2}{|c|}{$\begin{array}{l}\text { TN contents* } \\
\left(\mathrm{g} \mathrm{kg}^{-1}\right)\end{array}$} \\
\hline & $\mathrm{N}$ & $\mathrm{P}_{2} \mathrm{O}_{5}$ & $\mathrm{~K}_{2} \mathrm{O}$ & $\begin{array}{l}\text { Rice } \\
\text { straw }\end{array}$ & $\begin{array}{l}\text { Rice traw } \\
\text { compost }\end{array}$ & $\begin{array}{c}\text { Surface } \\
\text { layer } \\
(0-15 \mathrm{~cm})\end{array}$ & $\begin{array}{c}\text { Subsurface } \\
\text { layer } \\
(15-25 \mathrm{~cm})\end{array}$ & $\begin{array}{c}\text { Surface } \\
\text { layer } \\
(0-15 \mathrm{~cm})\end{array}$ & $\begin{array}{c}\text { Subsurface } \\
\text { layer } \\
(15-25 \mathrm{~cm})\end{array}$ \\
\hline PK & 0 & 68 & 83 & 0 & 0 & 18.6 & 13.7 & 1.40 & 1.00 \\
\hline NPK & 80 & 68 & 83 & 0 & 0 & 19.5 & 14.7 & 1.46 & 1.10 \\
\hline $\mathrm{RS}$ & 80 & 68 & 83 & 6 & 0 & 22.8 & 18.9 & 1.71 & 1.37 \\
\hline CM1 & 80 & 68 & 83 & 0 & 10 & 21.6 & 16.2 & 1.65 & 1.17 \\
\hline CM3 & 80 & 68 & 83 & 0 & 30 & 31.4 & 26.4 & 2.35 & 1.86 \\
\hline
\end{tabular}

${ }^{\dagger}$ Water contents of rice straw and rice straw compost were about 10 and $75 \%$, respectively.

*Data referred from Cheng et al. 2016.

in RS was applied at annual rates of $6 \mathrm{Mg} \mathrm{ha}^{-1}$, equivalent to the average yield of rice straw returning to the field after the harvest. Rice straw compost in CM1 treatment was applied at annual rates of $10 \mathrm{Mg} \mathrm{ha}^{-1}$, according local convention recommended by the local government (Table 1). An annual rate of $30 \mathrm{Mg}$ $\mathrm{ha}^{-1}$ of rice straw compost was applied in CM3 treatment, as three times larger than regular application rate (CM1). Rice straw was left on the soil surface after harvest and during the winter season. Rice straw compost was produced outdoors for about 2-3 years until the volume stabilized. The rice straw compost was incorporated at the plowed layer $(0-15 \mathrm{~cm})$ in the CM1 and CM3 treatments, while the NPK fertilizers were broadcasted before soil puddling and rice transplanting. The $\delta^{13} \mathrm{C}$ values of rice straw and rice straw compost were -28.7 and $27.4 \%$, while their $\delta^{15} \mathrm{~N}$ values were 1.6 and 5.9 $\%$, respectively. More information about the rice straw and rice straw compost can be found in Cheng et al. (2017).

\section{Soil sampling and analysis}

Soil samples were collected in November 2012, after 31 years of continuous rice cultivation. Soil samples were divided into surface $(0-15 \mathrm{~cm})$ and subsurface $(15-25 \mathrm{~cm})$ layers. The depth of the surface layer was chosen to correspond to the plowed layer (0$15 \mathrm{~cm}$ ) where fertilizers and organic matters are incorporated. The sampling depth of the subsurface layer was decided to down to $25 \mathrm{~cm}$ as rice roots have been observed at this depth. Nine soil cores were collected from each of the five plots, and three cores were mixed to make up one composite sample for soil analysis. Three samples were then obtained for each treatment plot. Samples were air-dried and sieved $(\varnothing<2 \mathrm{~mm})$ before analysis. SOC and TN were analyzed by dry combustion according to "Soil Normal Analysis Methods" (JSSSPN, 1986) using a CN-900 Analyzer (Sumika Chemical Analysis Service, Japan). The SOC and TN contents were shown in Table 1, which was referred from Cheng et al. (2016). 
Hot water- and water-extracted $C$ and $N$ measurements

Hot water-extracted organic carbon (HWEOC) and hot water-extracted nitrogen (HWEN) were obtained by adapting the method of Ghani et al. (2003). An amount of $20 \mathrm{~g}$ of airdried soils were placed in $50 \mathrm{ml}$ centrifuge tubes and shaken by hand for 2 minutes with $30 \mathrm{ml}$ deionized water and then placed in a water bath at $80^{\circ} \mathrm{C}$ for $16 \mathrm{hrs}$. After cooling, the tubes were centrifuged at $3000 \mathrm{rpm}$ for 30 minutes. The supernatant was filtered through a prewashed $0.45 \mu \mathrm{m}$ membrane filter (Millex-HV, Merck Millipore Ltd, Cork, Ireland). The supernatant was split into two subsamples for (i) the analysis of extracted organic carbon (EOC) and total extracted nitrogen (TEN) by thermal oxidation (TOC VCPH with TNM-1, Shimadzu, Japan), and (ii) the determination of inorganic $\mathrm{N}$ $\left(\mathrm{NH}_{4}{ }^{+}\right.$and $\left.\mathrm{NO}_{3}{ }^{-}\right)$by a colorimetric method
(JSSSPN, 1986; Cheng et al., 2016). Hot waterextracted organic nitrogen (HWEON) was calculated as the difference between HWEN and inorganic-N. The remaining solution was freeze-dried (FDU-2200, EYELA, Tokyo Rikakikai Co., Ltd, Japan) to measure the $\delta^{13} \mathrm{C}$ and $\delta^{15} \mathrm{~N}$ values.

The water-extracted organic carbon (WEOC) and water-extracted nitrogen (WEN) were obtained by shaking $20 \mathrm{~g}$ of air-dried soil samples with $30 \mathrm{ml}$ deionized water for 30 minutes (Shaking baths SB-13, AS One Co., $\mathrm{Ltd}$, Japan) at room temperature $\left(25^{\circ} \mathrm{C}\right)$, then centrifuged and filtered as were the hot waterextracted samples. The amounts and $\delta^{13} \mathrm{C}$ values of WEOC, and the amounts and $\delta^{15} \mathrm{~N}$ values of WEN were determined similarly to those of hot water extractions. We selected water at a soil:solution ratio of 2:3 was for getting enough amount of extracted $\mathrm{N}$ for measuring $\delta^{15} \mathrm{~N}$. 
Table 2. Changes in the amounts and $\delta{ }^{13} \mathrm{C}$ values of HWEOC, WEOC and $\triangle \mathrm{WEOC}$ (difference between hot water and water extractions) from the soil samples at surface $(0-15 \mathrm{~cm})$ and subsurface $(15-$ $25 \mathrm{~cm})$ layers after 31 years long-term experiment treated with inorganic fertilizers and organic matters.

\begin{tabular}{|c|c|c|c|c|c|c|c|}
\hline \multirow[t]{2}{*}{$\begin{array}{l}\text { Layers and } \\
\text { treatments }\end{array}$} & \multicolumn{2}{|c|}{$\begin{array}{l}\text { Amounts and } \delta^{13} \mathrm{C} \\
\text { values of } \mathrm{HWEOC}\end{array}$} & \multicolumn{2}{|c|}{$\begin{array}{l}\text { Amounts and } \delta^{13} \mathrm{C} \\
\text { values of WEOC }\end{array}$} & \multicolumn{2}{|c|}{$\begin{array}{l}\text { Amounts and } \delta^{13} \mathrm{C} \\
\text { values of } \Delta \mathrm{WEOC}\end{array}$} & \multirow[t]{2}{*}{$\begin{array}{l}\text { HWEOC/ } \\
\text { WEOC }\end{array}$} \\
\hline & $\left(\mathrm{mg} \mathrm{C} \mathrm{kg}^{-1}\right)$ & (\%o) & $\left(\mathrm{mg} \mathrm{C} \mathrm{kg}^{-1}\right)$ & $(\%)$ & $\left(\mathrm{mg} \mathrm{C} \mathrm{kg}^{-1}\right)$ & (\%o) & \\
\hline
\end{tabular}

Surface layer $(0-15 \mathrm{~cm})$

\begin{tabular}{llllllll} 
PK & 287 & -27.7 & 113 & -27.6 & 174 & -27.7 & 2.53 \\
NPK & 292 & -28.2 & 125 & -28.1 & 168 & -28.2 & 2.34 \\
RS & 387 & -28.2 & 168 & -28.3 & 219 & -28.1 & 2.30 \\
CM1 & 357 & -27.5 & 154 & -27.7 & 204 & -27.4 & 2.33 \\
CM3 & 462 & -27.6 & 187 & -27.7 & 276 & -27.5 & 2.48 \\
\hline
\end{tabular}

Subsurface layer $(15-25 \mathrm{~cm})$

\begin{tabular}{llllllll} 
PK & 179 & -27.3 & 81 & -27.8 & 98 & -27.0 & 2.22 \\
NPK & 212 & -27.6 & 102 & -27.4 & 110 & -27.8 & 2.08 \\
RS & 283 & -27.6 & 131 & -27.8 & 153 & -27.4 & 2.17 \\
CM1 & 269 & -26.5 & 123 & -27.0 & 145 & -26.1 & 2.18 \\
CM3 & 360 & -27.1 & 161 & -27.4 & 199 & -26.9 & 2.23 \\
\hline
\end{tabular}

\section{Data calculations and analysis}

Since there were no plot replications for each treatment, statistical analysis was not carried out in this paper. All data from the three pseudo-replicates were only used for the calculation of the average value for each treatment. For understanding the differences of soluble organic matter in quantity and quality between hot water and water extractions methods, the differences of WEOC (WEN) between hot water and water extractions ( $\triangle \mathrm{WEOC}$ and $\triangle \mathrm{WEN}$ ) were calculated as below for each treatment:

$\triangle \mathrm{WEOC}(\triangle \mathrm{WEN})\left(\mathrm{mg} \mathrm{kg} \mathrm{kg}^{-1}=\right.$ HWEOC (HWEN) - WEOC (WEN)
The $\delta^{13} \mathrm{C}$ value of $\triangle$ WEOC between hot water and water extractions was calculated by mass balance method as:

$\delta^{13} \mathrm{C}$ value of $\triangle$ WEOC $(\%)=($ HWEOC $\times$ $\left.\delta^{13} \mathrm{C}_{\mathrm{hweoc}}-\mathrm{WEOC} \times \delta^{13} \mathrm{C}_{\mathrm{weoc}}\right) / \Delta \mathrm{WEOC}$

where $\delta^{13} \mathrm{C}_{\text {hweoc }}$ and $\delta^{13} \mathrm{C}_{\text {weoc }}$ were $\delta^{13} \mathrm{C}$ values of HWEOC and WEOC for each treatment.

Similar to $\delta^{13} \mathrm{C}$, the $\delta^{15} \mathrm{~N}$ value of $\triangle \mathrm{WEN}$ between hot water and water extractions was calculated as:

$\delta^{15} \mathrm{~N}$ value of $\triangle \mathrm{WEN}(\%)=\left(\mathrm{HWEN} \times \delta^{15} \mathrm{~N}_{\mathrm{hwen}}\right.$ $\left.-\mathrm{WEN} \times \delta^{15} \mathrm{~N}_{\text {wen }}\right) / \triangle \mathrm{WEN}$

where $\delta^{15} \mathrm{~N}_{\text {hwen }}$ and $\delta^{15} \mathrm{~N}_{\text {wen }}$ were $\delta^{15} \mathrm{~N}$ values of HWEN and WEN for each treatment. 


\section{RESULTS}

\section{Hot water-and water-extracted organic carbon}

The changes in the amounts and $\delta^{13} \mathrm{C}$ values of HWEOC and WEOC from the soil samples at surface and subsurface layers after 31 years of long-term experiment treated with mineral fertilizers and organic matter are shown in Table 2. Long-term application of rice straw and compost increased the amounts of HWEOC and WEOC compared to control NPK in both surface and subsurface layers. In surface layers, the amounts of HWEOC and WEOC ranged from 287 to $462 \mathrm{mg} \mathrm{C} \mathrm{kg}^{-1}$ and from 113 to 187 $\mathrm{mg} \mathrm{C} \mathrm{kg}{ }^{-1}$, respectively, while the ratios of HWEOC to WEOC (HWEOC/WEOC) ranged from 2.30 to 2.53. In subsurface layers, the amounts of HWEOC and WEOC ranged from 179 to $360 \mathrm{mg} \mathrm{C} \mathrm{kg}^{-1}$ and from 81 to $161 \mathrm{mg} \mathrm{C}$ $\mathrm{kg}^{-1}$, while the HWEOC/WEOC ratios ranged from 2.08 to 2.23 (Table 2). The percentages of HWEOC and WEOC related to the SOC for the both layers ranged from 1.30 to $1.69 \%$ and from 0.59 to $0.76 \%$, respectively (Table 5). Compared to the larger variability of the HWEOC and WEOC amounts, the $\delta^{13} \mathrm{C}$ values of HWEOC and WEOC were more similar and ranged from -28.3 to $-27.5 \%$ for surface layer and from -27.8 to $-26.5 \%$ or for subsurface layer, respectively (Table 2). The difference between HWEOC and WEOC (noted $\triangle$ WEOC) is used to describe the organic carbon that could not be extracted by water extraction but extracted by the hot water extraction method. The $\delta^{13} \mathrm{C}$ values of $\triangle \mathrm{WEOC}$ were similar to those of HWEOC and WEOC (Table 2).

\section{Hot water- and water-extracted nitrogen}

The HWEN and WEN amounts and their $\delta^{15} \mathrm{~N}$ values changed from both layers after 31 years of long-term experiment treated with mineral fertilizers and organic matters are shown in Table 3. Long-term application of rice straw and compost increased amounts of HWEN and WEN compared to control NPK in both surface and subsurface layers. The amounts of HWEN and WEN in surface layer ranged from 11.8 to $24.0 \mathrm{mg} \mathrm{N} \mathrm{kg}^{-1}$ and from 4.2 to 7.5 $\mathrm{mg} \mathrm{N} \mathrm{kg}$, while the ratios of HWEN to WEN (HWEN/WEN) ranged from 2.78 to 3.20, respectively. In the subsurface layer the amounts of HWEN and WEN respectively ranged from 11.7 to $21.8 \mathrm{mg} \mathrm{N} \mathrm{kg}^{-1}$ and from 4.6 to $8.2 \mathrm{mg} \mathrm{N} \mathrm{kg}^{-1}$, while the ratios of HWEN/WEN ranged from 2.57 to 2.72 (Table 3). The percentages of HWEN and WEN relative to the $\mathrm{TN}$ for surface and subsurface layers ranged from 0.81 to $1.47 \%$ and from 0.29 to $0.56 \%$, respectively (Table 5). The $\delta^{15} \mathrm{~N}$ values of HWEN and WEN were lowest for the RS treatment and highest for the CM3 treatment (Table 3).

The difference between total extracted $\mathrm{N}$ and inorganic $\mathrm{N}\left(\mathrm{NO}_{3}{ }^{-}-\mathrm{N}\right.$ and $\left.\mathrm{NH}_{4}{ }^{+}-\mathrm{N}\right)$ was the organic $\mathrm{N}$. $\mathrm{NO}_{3}{ }^{-}-\mathrm{N}$ was undetected from both hot water and water extractions. The amounts of $\mathrm{NH}_{4}{ }^{+}-\mathrm{N}$ were higher in hot water extracts than in water extracts (Table 4). About $90 \%$ of the extracted $\mathrm{N}$ was organic form. For both surface and subsurface layers, HWEON and WEON were higher for treatments with organic matter application (RS, CM1 and CM3) compared to NPK and PK treatments (Table 4). 
Table 3. Changes in the amounts and $\delta^{15} \mathrm{~N}$ values of HWEN, WEN and $\triangle \mathrm{WEN}$ (difference between hot water and water extractions) from the soil samples at surface $(0-15 \mathrm{~cm})$ and subsurface $(15-25 \mathrm{~cm})$ layers after 31 years long-term experiment treated with inorganic fertilizers and organic matters.

\begin{tabular}{|c|c|c|c|c|c|c|c|}
\hline \multirow[t]{2}{*}{$\begin{array}{l}\text { Layers and } \\
\text { treatments }\end{array}$} & \multicolumn{2}{|c|}{$\begin{array}{l}\text { Amounts and } \delta^{15} \mathrm{~N} \\
\text { values of HWEN }\end{array}$} & \multicolumn{2}{|c|}{$\begin{array}{l}\text { Amounts and } \delta^{15} \mathrm{~N} \\
\text { values of WEN }\end{array}$} & \multicolumn{2}{|c|}{$\begin{array}{l}\text { Amounts and } \delta^{15} \mathrm{~N} \\
\text { values of } \Delta \mathrm{WEN}\end{array}$} & \multirow[t]{2}{*}{$\begin{array}{l}\text { HWEN/ } \\
\text { WEN }\end{array}$} \\
\hline & $\left(\mathrm{mg} \mathrm{N} \mathrm{kg}^{-1}\right)$ & $(\%)$ & $\left(\mathrm{mg} \mathrm{N} \mathrm{kg}^{-1}\right)$ & $(\%)$ & $\left(\mathrm{mg} \mathrm{N} \mathrm{kg}^{-1}\right)$ & $(\%)$ & \\
\hline \multicolumn{8}{|c|}{ Surface layer $(0-15 \mathrm{~cm})$} \\
\hline PK & 12.1 & 1.6 & 4.3 & 1.8 & 7.9 & 1.5 & 2.85 \\
\hline NPK & 11.8 & 1.2 & 4.2 & 1.2 & 7.6 & 1.2 & 2.79 \\
\hline $\mathrm{RS}$ & 15.3 & 0.8 & 5.4 & 1.0 & 10.0 & 0.6 & 2.85 \\
\hline CM1 & 17.5 & 2.0 & 6.3 & 2.3 & 11.2 & 1.9 & 2.78 \\
\hline CM3 & 24.0 & 3.6 & 7.5 & 3.8 & 16.5 & 3.5 & 3.20 \\
\hline \multicolumn{8}{|c|}{ Subsurface layer $(15-25 \mathrm{~cm})$} \\
\hline PK & 11.7 & 1.9 & 4.6 & 1.7 & 7.2 & 2.0 & 2.57 \\
\hline NPK & 14.2 & 1.8 & 5.2 & 2.6 & 9.0 & 1.4 & 2.72 \\
\hline $\mathrm{RS}$ & 16.0 & 0.8 & 6.0 & 1.0 & 10.0 & 0.7 & 2.65 \\
\hline CM1 & 17.1 & 2.3 & 6.5 & 2.8 & 10.6 & 2.0 & 2.63 \\
\hline CM3 & 21.8 & 3.8 & 8.2 & 4.0 & 13.6 & 3.6 & 2.67 \\
\hline
\end{tabular}

\section{C to $N$ ratios}

SOC/TN ratio of the bulk soil was similar for both surface and subsurface layers, ranging from 13.14 to 13.35 and from 13.39 to 14.15 , respectively (Table 6). But for water-extracted organic matter, the ratio of HWEOC/HWEON in surface soil ranged from 21.41 to 28.97 . It was clearly higher than that in subsurface soil, which ranged from 16.62 to 19.48 . The ratio of WEOC/WEON in surface soil (ranged from 27.84 to 36.13 ) was also clearly higher than that in subsurface soil (ranged from 19.49 to 24.09). The $\mathrm{C} / \mathrm{N}$ ratios of the different organic matter between hot water and water extraction ( $\triangle \mathrm{WEOC}) / \triangle \mathrm{WEON}$ ) had a similar trend like HWEOC/HWEON and WEOC/WEON (Table
6). Among the five treatments, RS treatment showed the highest $\mathrm{C} / \mathrm{N}$ ratio in hot water and water extractions, CM3 treatment showed the lowest HWEOC/HWEON in the surface layer. Results showed a consistent trend in $\mathrm{C} / \mathrm{N}$ ratios for all samples in the following order: water extraction $>$ hot water extraction $>$ bulk soil. This pattern was observed for both surface and subsurface layers. It was clear that in surface soil, applying compost (CM1 and CM3) have led to lower $\mathrm{C} / \mathrm{N}$ ratio, compared to other treatments under both hot water and water extraction. However, there was no clear observation for subsurface soil (Table 6). 
Table 4. Changes in the amounts of HWEON and WEON, and hot water and water soluble $\mathrm{NH}_{4}{ }^{+}-\mathrm{N}$ from the soil samples at surface $(0-15 \mathrm{~cm})$ and subsurface $(15-25 \mathrm{~cm})$ layers after 31 years long-term experiment treated with inorganic fertilizers and organic matters.

\begin{tabular}{|c|c|c|c|c|c|c|c|c|}
\hline \multirow[t]{3}{*}{$\begin{array}{l}\text { Layers and } \\
\text { treatments }\end{array}$} & \multicolumn{2}{|c|}{$\begin{array}{l}\text { Amounts of } \\
\text { EON }\end{array}$} & \multirow{2}{*}{$\begin{array}{l}\text { Difference } \\
\text { of EON } \\
\text { between } \\
\text { hot water } \\
\text { and water }\end{array}$} & \multicolumn{2}{|c|}{$\begin{array}{l}\text { Amounts of } \\
\mathrm{NH}_{4}{ }^{+}-\mathrm{N} \\
\end{array}$} & \multirow{2}{*}{$\begin{array}{l}\text { Difference } \\
\text { of } \\
\text { extracted } \\
\mathrm{NH}_{4}{ }^{+}-\mathrm{N} \\
\text { between } \\
\text { hot water }\end{array}$} & \multicolumn{2}{|c|}{$\begin{array}{l}\text { Percentage of } \\
\text { EON to EN }\end{array}$} \\
\hline & $\begin{array}{l}\text { by hot } \\
\text { water }\end{array}$ & $\begin{array}{l}\text { by } \\
\text { water }\end{array}$ & & $\begin{array}{l}\text { by hot } \\
\text { water }\end{array}$ & $\begin{array}{l}\text { by } \\
\text { water }\end{array}$ & & $\begin{array}{l}\text { by hot } \\
\text { water }\end{array}$ & $\begin{array}{l}\text { by } \\
\text { water }\end{array}$ \\
\hline & \multicolumn{5}{|c|}{$\left(\mathrm{mg} \mathrm{N} \mathrm{kg}^{-1}\right)$} & & \multicolumn{2}{|l|}{$(\%)$} \\
\hline \multicolumn{9}{|c|}{ Surface layer $(0-15 \mathrm{~cm})$} \\
\hline PK & 10.6 & 3.6 & 6.3 & 1.5 & 0.6 & 0.9 & 87.7 & 85.4 \\
\hline NPK & 10.3 & 3.6 & 6.4 & 1.5 & 0.6 & 0.8 & 87.6 & 85.0 \\
\hline $\mathrm{RS}$ & 13.4 & 4.7 & 9.3 & 2.0 & 0.7 & 1.3 & 87.0 & 86.3 \\
\hline CM1 & 15.7 & 5.5 & 9.3 & 1.7 & 0.8 & 1.0 & 90.1 & 88.0 \\
\hline CM3 & 21.6 & 6.6 & 12.9 & 2.4 & 0.9 & 1.5 & 90.1 & 87.9 \\
\hline \multicolumn{9}{|c|}{ Subsurface layer $(15-25 \mathrm{~cm})$} \\
\hline PK & 10.7 & 4.1 & 5.2 & 1.1 & 0.4 & 0.6 & 91.0 & 90.4 \\
\hline NPK & 12.8 & 4.6 & 7.6 & 1.5 & 0.6 & 0.9 & 89.8 & 88.9 \\
\hline $\mathrm{RS}$ & 14.5 & 5.4 & 9.3 & 1.5 & 0.6 & 0.9 & 90.9 & 90.0 \\
\hline CM1 & 15.7 & 5.9 & 8.6 & 1.4 & 0.6 & 0.8 & 91.8 & 91.2 \\
\hline CM3 & 19.8 & 7.3 & 10.0 & 2.0 & 0.9 & 1.1 & 91.0 & 89.6 \\
\hline
\end{tabular}

\section{DISCUSSION}

\section{Amounts and $\delta^{13} \mathrm{C}$ values of hot water and water extraction carbon}

Extractable organic carbon is highly mobile in soils and was reported to be an important available source of energy for microorganisms, usually accounting for less than $2 \%$ of the SOC (Chantigny et al., 2014; Guigue et al., 2015). Although there are many analytical procedures to separate the EOC from soils, both WEOC and HWEOC $\left(80^{\circ} \mathrm{C}\right.$ and $\left.16 \mathrm{hrs}\right)$ are frequently used (Moriizumi and Matsunaga, 2011; Chantigny et al., 2014; Guigue et al., 2015). Our Journal of Wetlands Environmental Management Vol 6, No 2 (2018) 60 - 73 http://dx.doi.org/10.20527/jwem.v6i2.176 results showed that the percentages of WEOC and HWEOC related to the SOC for surface and subsurface layers ranged from 0.59 to $0.76 \%$ and from 1.30 to $1.69 \%$, respectively (Table 5). On the average for the five treatments, HWEOC was 2.40 and 2.18 times higher than WEOC in surface and subsurface layers, respectively (Table 2), indicating that hot water at $80^{\circ} \mathrm{C}$ is more efficient to extract EOC from soil. The $\delta^{13} \mathrm{C}$ values of HWEOC and WEOC (ranged from -28.3 to $-26.5 \%$ for both surface and subsurface layers, Table 2) were closer to the $\delta{ }^{13} \mathrm{C}$ values of the rice straw (-28.3\%o) and rice straw compost $(-27.4 \%)$ and lower than lower than the value of original soil $(-22.5 \%)$ and 
bulk soils of treatments ranged from -25.7 to 23.2\%o (unpublishing data). Guigue et al. (2015) also reported that the $\delta^{13} \mathrm{C}$ in water extracts was significantly less negative than in bulk SOC.
These results indicated that both the sources of HWEOC and WEOC were mostly from the rice plant photosynthesis, not from the original soil.

Table 5. The percentage of hot water and water extracted C (HWEOC and WEOC) and decomposed $\mathrm{C}$ (Dec-C) to the SOC, and extracted N (HWEN and and WEN) mineralized (N-min) for the soil samples from different long-term inorganic fertilizer and organic matter treatments at surface $(0-15$ $\mathrm{cm})$ and subsurface $(15-25 \mathrm{~cm})$ layers.

\begin{tabular}{|c|c|c|c|c|c|c|}
\hline \multirow{2}{*}{$\begin{array}{l}\text { Layers and } \\
\text { treatments }\end{array}$} & HWEOC & WEOC & Dec-C ${ }^{*}$ & HWEN & WEN & Min-N* \\
\hline & \multicolumn{3}{|c|}{ per SOC (\%) } & \multicolumn{3}{|c|}{ per TN $(\%)$} \\
\hline \multicolumn{7}{|c|}{ Surface layer $(0-15 \mathrm{~cm})$} \\
\hline PK & 1.55 & 0.61 & 2.64 & 0.87 & 0.30 & 8.39 \\
\hline NPK & 1.50 & 0.64 & 2.84 & 0.81 & 0.29 & 7.44 \\
\hline $\mathrm{RS}$ & 1.69 & 0.74 & 2.89 & 0.90 & 0.32 & 8.31 \\
\hline CM1 & 1.65 & 0.71 & 2.83 & 1.06 & 0.38 & 8.06 \\
\hline CM3 & 1.47 & 0.60 & 2.25 & 1.02 & 0.32 & 6.92 \\
\hline \multicolumn{7}{|c|}{ Subsurface layer $(15-25 \mathrm{~cm})$} \\
\hline PK & 1.30 & 0.59 & 2.38 & 1.18 & 0.46 & 7.18 \\
\hline NPK & 1.44 & 0.69 & 1.90 & 1.29 & 0.47 & 6.21 \\
\hline $\mathrm{RS}$ & 1.50 & 0.69 & 2.13 & 1.17 & 0.44 & 6.98 \\
\hline CM1 & 1.66 & 0.76 & 1.99 & 1.47 & 0.56 & 6.80 \\
\hline CM3 & 1.36 & 0.61 & 1.94 & 1.17 & 0.44 & 6.26 \\
\hline
\end{tabular}

*The data of Dec-C and Min-N were referred from Cheng et al . (2016), which were measured by anaerobic incubation at $30{ }^{\circ} \mathrm{C}$ for 8 weeks.

Amounts and $\delta^{15} N$ values of hot water and water extraction nitrogen

There are many studies on the extractable organic $\mathrm{N}$ and dissolved organic $\mathrm{N}$ in soils to predict $\mathrm{N}$ mineralization, $\mathrm{N}$ leaching, and to evaluate agricultural (nutrient) management practices (Curtin et al., 2006; Ros et al., 2009), but very few on determining $\delta^{15} \mathrm{~N}$ values of WEN or WEON (Makarov et al., 2015). HWEN (or WEN) could be divided into two parts of organic $\mathrm{N}$ and inorganic $\mathrm{N}\left(\mathrm{NO}_{3}{ }^{-}-\mathrm{N}\right.$ and $\mathrm{NH}_{4}{ }^{+}-$ $\mathrm{N})$. The $\mathrm{NO}_{3}{ }^{-}-\mathrm{N}$ was not detected in all hot water or water extraction, and around 85 92\% of HWEN and WEN were organic form in this study (Table 3 and 4). Our results showed that the percentages of WEN and HWEN related to the $\mathrm{TN}$ at surface and subsurface layers ran 67 from 0.29 to $0.56 \%$ and from 0.81 to $1.47 \%$ 
(Table 5). The ratios of HWEN/TN and WEN/TN were lower than those of HWEOC/SOC and WEOC/SOC, respectively, which indicates that the proportion of extractable SOC was higher than that of extractable $\mathrm{TN}$, leading to higher WEOC/WEON and HWEOC/HWEON ratios compared to SOC/TN (Table 6). To our knowledge, our research is the first to report the changes in $\delta^{15} \mathrm{~N}$ values of HWEN and WEN in a soil from an LTE in Japan. It was interesting that the $\delta^{15} \mathrm{~N}$ values of HWEN and WEN were the lowest for the RS treatment and the highest at CM3 treatment (Table 3). The enriched $\delta^{15} \mathrm{~N}$ in CM3 treatment was due to extra-organic $\mathrm{N}$ addition from rice straw compost (Yoneyama et al., 1990; Nishida et al., 2007). The depleted $\delta^{15} \mathrm{~N}$ in RS may be due to an instant immobilization of the mineral $\mathrm{N}$ fertilizer by soil microorganisms due to high $\mathrm{C} / \mathrm{N}$ rice straw application.

Table 6. The ratios of SOC/TN, HWEOC/HWEON, WEOC/WEON, $\triangle$ WEOC/ $\triangle$ WEON (difference between hot water and water extractions), Dep-C/Min-N ( $\mathrm{C}$ decomposition potential/N mineralization potential) from the soil samples at surface $(0-15 \mathrm{~cm})$ and subsurface $(15-25 \mathrm{~cm})$ layers after 31 years long-term experiment treated with inorganic fertilizers and organic matters.

\begin{tabular}{cccccc}
\hline $\begin{array}{l}\text { Layers and } \\
\text { treatments }\end{array}$ & $\begin{array}{c}\text { SOC } \\
\text { /TN* }\end{array}$ & $\begin{array}{l}\text { HWEOC/ } \\
\text { HWEON }\end{array}$ & $\begin{array}{l}\text { WEOC/ } \\
\text { WEON }\end{array}$ & $\begin{array}{c}\Delta \text { WEOC/ } \\
\Delta \text { WEON }\end{array}$ & $\begin{array}{c}\text { Dep-C/ } \\
\text { Min-N* }\end{array}$ \\
\hline \multicolumn{2}{l}{ Surface layer $(0-15 \mathrm{~cm})$} & & & & \\
PK & 13.26 & 26.99 & 31.19 & 27.38 & 4.18 \\
NPK & 13.34 & 28.41 & 34.82 & 26.20 & 5.09 \\
RS & 13.35 & 28.97 & 36.13 & 23.50 & 4.64 \\
CM1 & 13.14 & 22.71 & 27.84 & 21.88 & 4.62 \\
CM3 & 13.33 & 21.41 & 28.36 & 21.30 & 4.33 \\
Subsurface layer $(15-25 \mathrm{~cm})$ & & & & \\
PK & 13.79 & 16.74 & 19.49 & 18.99 & 4.57 \\
NPK & 13.39 & 16.62 & 21.97 & 14.42 & 4.09 \\
RS & 13.77 & 19.48 & 24.09 & 16.46 & 4.21 \\
CM1 & 13.86 & 17.07 & 20.78 & 16.89 & 4.06 \\
CM3 & 14.15 & 18.15 & 22.03 & 19.85 & 4.38 \\
\hline
\end{tabular}

*SOC/TN and Dep-C/Min-N were refered from Cheng et al. (2016), Dep-C and Min-N were measured by anaerobic incubation at $30^{\circ} \mathrm{C}$ for 8 weeks.

The ratios of stratification

\section{(surface/subsurface) and C to $N(C / N)$}

It is not a surprise that surface layer contains more water extracted organic matter than subsurface layer (Kusumawardani et al., 2017), however, the stratification ratios of the two soil layers were stable with bulk soil, hot water and water extractions, and no differences were found among them (Table 7). The stratification ratios of HWEN for the surface and subsurface layers were close to 1 (0.99 for average), indicating 
that there was no difference in the amount of available $\mathrm{N}$ in surface and subsurface layers. This may be explained by the fact that available $\mathrm{N}$ in the surface layer was absorbed by rice plants more than subsurface layer. The stratification of WEN (0.90 for average) was lower than HWEN, which indicates that room temperature water extracted $\mathrm{N}$ in the surface layer was removed more easily than in the subsurface layer through absorption by rice plants or leaching processes, as reported by Ros et al. (2009).

The $\mathrm{C} / \mathrm{N}$ ratio of organic matter is a key indicator related to $\mathrm{C}$ decomposition and $\mathrm{N}$ mineralization potentials, as well as instant immobilization in rice paddy. $\mathrm{C} / \mathrm{N}$ ratio of rice straw decreased from 50-70 to around 10 in a paddy soil after the straw was buried into the soil during five years, as reported in a study based on glass fiber bag method (Shiga et al., 1985). There should be larger variations of the $\mathrm{C} / \mathrm{N}$ ratios among the intermediate products from plant tissue and SOC decomposition, which dissolved in the hot water- or waterextracted solutions. Our results showed that there were large differences among SOC/TN, HWEOC/HWEON, WEOC/WEON, and decomposition $\mathrm{C} /$ mineralization $\mathrm{N}$ (Dep-C/MinN) (Table 6). Dep-C and Min-N are the active fractions of soil organic matter, and were measured by anaerobic incubation experiment with 8 weeks at $30{ }^{\circ} \mathrm{C}$ (Cheng et al., 2016). Compared with ratios of SOC/TN around 13.14 to 14.15 , ratios of WEOC/WEON were the highest (ranging from 19.49 to 36.13), followed by HWEOC/HWEON (ranging from 16.62 to 28.97). The difference between hot water and water extracts $(\triangle \mathrm{WEOC} / \triangle \mathrm{WEON})$ was similar to HWEOC/HWEON (Table 6). The higher $\mathrm{C} / \mathrm{N}$ ratio of the dissolved organic matter in hot water and water extractions indicated that the organic matter was on the process of soil humification or on both decomposition and humification processes simultaneously. Compared to the high Journal of Wetlands Environmental Management Vol 6, No 2 (2018) 60 - 73

http://dx.doi.org/10.20527/jwem.v6i2.176
C/N of HWEOC/HWEON, WEOC/WEON, the $\mathrm{C} / \mathrm{N}$ ratio of Dep-C to Min-N was very low, from 4.06 to 5.09 (Table 6), indicating that the decomposing organic matter during the anaerobic incubation process was from soil microbial biomass and soil protein (Rillig et al., 2007; Moriizumi et al., 2015).

\section{CONCLUSION}

In this study, we evaluated the effects of long-term application of mineral fertilizers and/or organic matters on amounts of their stable isotopes of hot water- and water-extracted carbon and nitrogen of the soil samples collected from a single rice paddy in Yamagata, northeastern Japan. Soil:water ratio of 2:3 was used for this study. The $\delta^{13} \mathrm{C}$ values of hot water and water extractions were similar among treatments and close to the $\delta^{13} \mathrm{C}$ values of rice straw and rice straw compost. We suppose that long-term application of rice straw and rice straw compost did not alter the $\delta^{13} \mathrm{C}$ values of hot water and water extractions. On the other hand, $\delta^{15} \mathrm{~N}$ values of HWEN and WEN decreased in RS but increased in CM3 treatments compared to NPK treatment. Based on these results, we propose that hot water and water extraction could be used to understand how soil organic matter (in term of SOC and $\mathrm{TN}$ ) changed by rice straw and rice straw compost applications in the long-term rice paddies. Our results therefore give recommendations on how to consider $\mathrm{C}$ and $\mathrm{N}$ amounts and their stable isotopes fractionations in different pools by hot water, water extrac 69 of the soils. However, the ratio of soil to water extracted solution was 2:3 (w/w) in this study, which was lower than normal $(1: 5 \sim 1: 10)$, the amounts of HWEM of our results may be lower than normal extraction methods. Further researches should be carried out to understand the difference.

\section{ACKNOWLEDGMENTS}


First author, Toan Nguyen-Sy, appreciates the MEXT scholarship for supporting his studies in Japan. We thank Dr. Katsumi Kumagai and Mr. Hiroyuki Shiono for providing the soil samples from the long-term experiment which is carrying out in Yamagata Integrated Agricultural Research Center, Dr. D. Pham-Viet and Dr. D. Pham-Duy for their help to use TOC VCPH with TNM-1, Ms. S. Honma for her help to use EA-IRMS, and Ms. C. Sato and M. Takai, and Mr. S. Sato K. Kasahara in Plant Nutrition and Soil Science Lab, Yamagata University for their help to collect soil samples.

Table 7. The stratification ratios of surface $(0-15 \mathrm{~cm})$ and subsurface $(15-25 \mathrm{~cm})$ layers for the parameters related to $\mathrm{C}$ and $\mathrm{N}$ for soil samples from different long-term inorganic fertilizer and organic matter treatments.

\begin{tabular}{|c|c|c|c|c|c|c|c|c|}
\hline \multirow[t]{2}{*}{ Treatments } & \multirow{2}{*}{$\frac{\mathrm{SOC}^{*}}{\text { Amount }}$} & \multicolumn{2}{|c|}{ HWEOC } & \multicolumn{2}{|l|}{ WEOC } & \multicolumn{2}{|c|}{$\triangle \mathrm{WEOC}$} & \multirow{2}{*}{$\frac{\text { Dec-C } *}{\text { Amount }}$} \\
\hline & & Amount & $\delta^{13} \mathrm{C}$ & Amount & $\delta^{13} \mathrm{C}$ & Amount & $\delta^{13} \mathrm{C}$ & \\
\hline PK & 1.35 & 1.60 & 1.01 & 1.41 & 0.99 & 1.77 & 1.03 & 1.51 \\
\hline NPK & 1.32 & 1.38 & 1.02 & 1.23 & 1.03 & 1.52 & 1.01 & 1.98 \\
\hline $\mathrm{RS}$ & 1.21 & 1.37 & 1.02 & 1.29 & 1.02 & 1.43 & 1.03 & 1.64 \\
\hline CM1 & 1.34 & 1.33 & 1.04 & 1.25 & 1.03 & 1.40 & 1.05 & 1.90 \\
\hline CM3 & 1.19 & 1.29 & 1.02 & 1.16 & 1.01 & 1.39 & 1.02 & 1.38 \\
\hline
\end{tabular}

\begin{tabular}{|c|c|c|c|c|c|c|c|c|}
\hline \multirow[t]{2}{*}{ Treatments } & \multirow{2}{*}{$\frac{\mathrm{TN}^{*}}{\text { Amount }}$} & \multicolumn{2}{|l|}{ HWEN } & \multicolumn{2}{|l|}{ WEN } & \multicolumn{2}{|l|}{$\triangle \mathrm{WEN}$} & \multirow{2}{*}{$\frac{\text { Min- } \mathrm{N}^{*}}{\text { Amount }}$} \\
\hline & & Amount & $\delta^{15} \mathrm{~N}$ & Amount & $\delta^{15} \mathrm{~N}$ & Amount & $\delta^{15} \mathrm{~N}$ & \\
\hline PK & 1.41 & 1.03 & 0.86 & 0.93 & 1.05 & 1.10 & 0.77 & 1.65 \\
\hline NPK & 1.33 & 0.83 & 0.65 & 0.81 & 0.47 & 0.84 & 0.85 & 1.59 \\
\hline $\mathrm{RS}$ & 1.25 & 0.96 & 0.95 & 0.89 & 1.02 & 1.00 & 0.91 & 1.49 \\
\hline CM1 & 1.41 & 1.02 & 0.89 & 0.97 & 0.85 & 1.05 & 0.93 & 1.67 \\
\hline CM3 & 1.26 & 1.10 & 0.96 & 0.92 & 0.95 & 1.21 & 0.98 & 1.39 \\
\hline
\end{tabular}

*The data of SOC, TN, Dec-C and Min-N were referred from Cheng et al . (2016). Dec-C and Min- $\mathrm{N}$ were measured by anaerobic incubation at $30{ }^{\circ} \mathrm{C}$ for 8 weeks.

\section{REFERENCES}

Azuma H, Uezono I, Nohara S, Takahashi S, Kato N. 2015. Rapid method for estimating nitrogen in air-dried paddy soils based on the total organic carbon (TOC) extracted from oven-dried soils shaken in water. Japanese Journal of Soil Science and Plant Nutrition. 86: 188-197 (in Japanese with English summary).
Chantigny MH. 2003. Dissolved and waterextractable organic matter in soils: a review on the influence of land use and management practices. Geoderma. 113: 357-380.

Chantigny $\mathrm{MH}$, Harrison-Kirk $\mathrm{T}$, Curtin D, Beare M. 2014. Temperature and duration of extraction affect the biochemical composition of soil water-extractable 
organic matter. Soil Biology and Biochemistry. 75: 161-166.

Cheng W, Padre AT, Sato C, Shiono H, Hattori S, Kajihara A, Aoyama M, Tawaraya K, Kumagai K. 2016. Changes in the soil C and $\mathrm{N}$ contents, $\mathrm{C}$ decomposition and $\mathrm{N}$ mineralization potentials in a rice paddy after long-term application of inorganic fertilizers and organic matter. Soil Science and Plant Nutrition. 62: 212-219.

Cheng W, Padre AT, Shiono H, Sato C, Nguyen-Sy T, Tawaraya K, Kumagai K. 2017. Changes in the $\mathrm{pH}, \mathrm{EC}$, available $\mathrm{P}$, SOC and TN stocks in a single rice paddy after long-term application of inorg 70 fertilizers and organic matters in a curu temperate region of Japan. Journal of Soils and Sediments. 17: 1834-1842

Cheng W, Sakai H, Yagi K, Hasegawa T. 2010. Combined effects of elevated $\left[\mathrm{CO}_{2}\right]$ and high night temperature on carbon assimilation, nitrogen absorption, and the allocations of $\mathrm{C}$ and $\mathrm{N}$ by rice (Oryza sativa L.). Agricultural and Forest Meteorology. 150: 1174-1181.

Cheng W, Yagi K, Akiyama H, Nishimura S, Sudo S, Fumoto T, Hasegawa T, Hartley AE, Megonigal JP. 2007. An empirical model of soil chemical properties that regulate methane production in Japanese rice paddy soils. Journal of Environmental Quality. 36: 1920-1925.

Cheng W, Yagi K, Xu H, Sakai H, Kobayashi K. 2005. Influence of elevated concentrations of atmospheric $\mathrm{CO}_{2}$ on $\mathrm{CH}_{4}$ and $\mathrm{CO}_{2}$ entrapped in rice-paddy soil. Chemical Geology. 218: 15-24.

Choi WJ, Kwak JH, Lim SS, Park HJ, Chang SX, Lee SM, Arshad MA, Yun SI, Kim HY. 2017. Synthetic fertilizer and livestock manure differently affect $\delta^{15} \mathrm{~N}$ in the agricultural landscape: a review. Agriculture, Ecosystems \& Environment. 237: 1-15.

Curtin D, Wright CE, Beare $\mathrm{MH}$, McCallum FM. 2006. Hot water-extractable nitrogen as an indicator of soil nitrogen availability. Soil Science Society of America Journal. 70: 1512-1521.

Ghani A, Dexter M, Perrott KW. 2003. Hotwater extractable carbon in soils: a sensitive measurement for determining impacts of fertilisation, grazing and cultivation. Soil Biology and Biochemistry. 35: 1231-1243.

Guigue J, Lévêque J, Mathieu O, SchmittKopplin P, Lucio M, Arrouays D, Jolivet C, Dequiedt S, Prévost-Bouré NC, Ranjard L. 2015. Water-extractable organic matter linked to soil physicochemistry and microbiology at the regional scale. Soil Biology and Biochemistry. 84: 158-167.

Guigue J, Mathieu O, Lévêque J, Mounier S, Laffont R, Maron PA, Navarro N, Chateau-Smith C, Amiotte-Suchet P, Lucas Y. 2014. A comparison of extraction procedures for waterextractable organic matter in soils. European Journal of Soil Science. 65: 520-530.

Hopkins DW, Waite IS, McNicol JW, Poulton PR, Macdonald AJ, O'Donnell AG. 2009. Soil organic carbon contents in long-term experimental grassland plots in the UK (Palace Leas and Park Grass) have not changed consistently in recent decades. Global Change Biology. 15: 1739-1754.

Kanamori T. 2000. Present state of long-term field experiments on successive 
application of chemical fertilizers and composts as organic matters in national and prefectural research stations. Japanese Journal of Soil Science and Plant Nutrition. 71: 286-293 (in Japanese).

Körschens M. 2006. The importance of longterm field experiments for soil science and environmental research - A review. Plant, Soil and Environment. 52: 1-8.

Kusumawardani PN, Cheng W, Purwanto BH, Utami SNH. 2017. Changes in the soil $\mathrm{pH}$, $\mathrm{EC}$, available-P, DOC and inorganic-N after land use change from rice paddy in northeast Japan. Journal of Wetlands Environmental Management. 5: 53-61.

JSSSPN (Japanese Society of Soil Science

Plant Nutrition). 1986. Soil Normal Analysis Methods, Hakuyusha Press, Tokyo (in Japanese).

Makarov MI, Malysheva TI, Menyailo OV, Soudzilovskaia NA, Van Logtestijn RSP, Cornelissen JHC. 2015. Effect of $\mathrm{K}_{2} \mathrm{SO}_{4}$ concentration on extractability and isotope signature $\left(\delta^{13} \mathrm{C}\right.$ and $\left.\delta^{15} \mathrm{~N}\right)$ of soil $\mathrm{C}$ and $\mathrm{N}$ fractions. European Journal of Soil Science. 66: 417-426.

Moriizumi M, Matsunaga T. 2011. Molecular weight separation of hot-water extractable soil organic matter using highperformance size exclusion chromatography with chemiluminescent nitrogen detection. Soil Science and Plant Nutrition. 57: 185-189.

Moriizumi M, Uezono I, Matsunaga T, Kato N. 2015. Decomposition characteristics of hot-water-extractable soil organic nitrogen during aerobic soil incubation. Japanese Journal of Soil Science and Plant Nutrition. 86: 8-16 (in Japanese).
Nakajima M, Cheng W, Tang S, Hori Y, Yaginuma E, Hattori S, Hanayama S, Tawaraya K, Xu X. 2016. Modeling aerobic decomposition of rice straw during off-rice season in an Andisol paddy soil in a cold temperate region, Japan: Effects of soil temperature and moisture. Soil Science and Plant Nutrition. 62: 9098.

Nishida M, Iwaya K, Sumida H, Kato N. 2007. Changes in natural ${ }^{15} \mathrm{~N}$ abundance in paddy soils under different, long-term soil management regimes in the Tohoku region of Japan. Soil Science and Plant Nutrition. 53: 310-317.

Rasmussen PE, Goulding KWT, Brown JR, Grace PR, Janzen HH, Körschens M. 1998. Long-term agroecosystem experiments: assessing agricultural sustainability and global change. Science. 282: 893-896.

Richter DD, Hofmockel M, Callaham MA, Powlson DS, Smith P. 2007. Long-term soil experiments: keys to managing earth's rapidly changing ecosystems. Soil Science Society of America Journal. 71: 266-279.

Rillig MC, Caldwell BA, Wosten HAB, Sollins P. 2007. Role of proteins in soil carbon and nitrogen storage: controls on persistence. Biogeochemistry. 85: 25-44.

Ros GH, Hoffland E, van Kessel C, Temminghoff EJM. 2009. Extractable and dissolved soil organic nitrogen - A quantitative assessment. Soil Biology and Biochemistry. 41: 1029-1039.

Sparling G, Vojvodic-Vukovic M, Schipper LA. 1998. Hot-water-soluble $\mathrm{C}$ as a simple measure of labile soil organic matter: the relationship with microbial biomass $\mathrm{C}$. 
Soil Biology and Biochemistry. 30: 14691472.

Shiga H, Ohyama N, Maeda K, Suzuki M. 1985. An evaluation of different organic materials based on their decomposition patterns in paddy soils. Bulletin of the National Agriculture Research Center, No. 5, pp. 1-19 (In Japanese with English summary).

van Ginkel JH, Merckx R, van Veen JA. 1994. Microbial biomass method based on soluble carbon in the soil solution. Soil Biology and Biochemistry. 26: 417-419.

Werth M, Kuzyakov Y. 2010. ${ }^{13} \mathrm{C}$ fractionation at the root-microorganisms-soil interface: A review and outlook for partitioning studies. Soil Biology and Biochemistry. 42: 1372-1384.

Yamagata Agricultural Research Station. 1983. Yamagata Agricultural Research Station Annual Report. No. 59-5, pp. 42-52 (in Japanese).

Yoneyama T, Kouno K, Yazaki J. 1990. Variation of natural ${ }^{15} \mathrm{~N}$ abundance of crops and soils in Japan with special reference to the effect of soil conditions and fertilizer application. Soil Science and Plant Nutrition. 36: 667-675.

Yoneyama T, Nakanishi Y, Morita A, Liyanage BC. 2001. $\delta^{13} \mathrm{C}$ values of organic carbon in cropland and forest soils in Japan. Soil Science and Plant Nutrition. 47: 17-26. 